\title{
FAKTOR-FAKTOR YANG MEMPENGARUHI KELULUSAN UJI KOMPETENSI MAHASISWA PROFESI NERS STIKES JENDERAL ACHMAD YANI YOGYAKARTA
}

\section{FACTORS THAT INFLUENCE THE GRADUATION OF COMPETENCE TESTS NURSE PROFESSION STUDENTS STIKES GENERAL ACHMAD YANI YOGYAKARTA}

\author{
Deby Zulkarnain Rahadian Syah ${ }^{1}$, Rahayu Iskandar ${ }^{2}$, Sujono Riyadi ${ }^{3}$ \\ Dosen Program Studi Keperawatan Stikes Jenderal Achmad Yani Yogyakarta
}

\begin{abstract}
ABSTRAK
Penekanan pengembangan dan pembinaan pendidikan tinggi keperawatan di masa depan lebih diarahkan pada upaya meningkatkan mutu pendidikan, sehingga lulusan benar-benar menunjukkan sikap profesional, menguasai ilmu pengetahuan keperawatan dalam kadar yang memadai, serta menguasai keterampilan profesional keperawatan. Kompetensi seorang perawat adalah sesuatu yang ditampilkan secara menyeluruh oleh seorang perawat dalam memberikan pelayanan professional kepada klien, mencakup pengetahuan, keterampilan, dan pertimbangan yang dipersyaratkan dalam situasi praktik.Penelitian ini merupakan penelitian deskriptif korelasi. Penelitian dilakukan di Stikes Jenderal Achmad Yani Yogyakarta. Penggunaan pendekatancross-sectional pada penelitian ini karena tidak adanya intervensi apa pun dan pengambilan data dilakukan sekali waktu. Hasil penelitian didapatkan faktor IPK S1 keperawatan $p$ 0,002 dengan $\mathrm{r} 0,836$ ada hubungan, IPK ners $p 0,106$ tidak ada hubungan, sarana prasarana akademik $p 0,001$ dengan $\mathrm{r} 1$ ada hubungan, faktor lingkungan $p 0,807$ tidak ada hubungan, tingkat spiritual $p 0,617$ tidak ada hubungan, tipe kepribadian $p 0,846$ tidak ada hubungan, tingkat kecemasan $p 0,143$ tidak ada hubungan, jenis kelamin $p 1,0$ tidak ada hubungan, dan program peminatan $p 0,976$ tidak ada hubungan.Faktor yang mempengaruhi kelulusan uji kompetensi adalahg IPK akademik S1 keperawatan dan sarana prasarana akademik.
\end{abstract}

Kata kunci: Uji kompetensi, IPK, akademik, kepribadian, spiritual, cemas, jenis kelamin, peminatan

\begin{abstract}
The emphasis on developing and nurturing higher education in nursing in the future is more directed at improving the quality of education, so that graduates really show a professional attitude, mastering nursing science in an adequate level, and mastering nursing professionals. A nurse's competence is something that a nurse carries out in providing professional services to clients, the necessary knowledge spaces, skills, and considerations in practice situations. This research is a descriptive research. The research was conducted at Stikes General Achmad Yani Yogyakarta. The data use of cross sectional approach in this study because there is no intervention and data retrieval. The result of this research is got the achievement index of Stata-1 nursing $\mathrm{p}$ 0,002 with $\mathrm{r} 0,836$ have relationship achievement indexners p 0,106 no relation, academic infrastructure p 0,001 with $\mathrm{r} 1$ there is relation, environmental factor $\mathrm{p} 0,807$ no relation, spiritual level $\mathrm{p} 0,617$ no relation, personality type $\mathrm{p} 0.846$ no relationship, anxiety level p 0.143 no relationship, sex p 1.0 no relationship, and program $\mathrm{p} \mathrm{p}$ 0,976 no relationship. Factors affecting the graduation of competency test are achievement index of academic undergraduate of nursing and academic facilities.
\end{abstract}

Keywords: Competency test, achievement index, academy, personality, spiritual, anxiety, gender, concentration 


\section{PENDAHULUAN}

Uji kompetensi adalah proses pengukuran pengetahuan, keterampilan, dan perilaku peserta didik pada perguruan tinggi yang menyelenggarakan program studi keperawatan. Mahasiswa keperawatan baik D3 maupun S1 pada akhir masa studinya diwajibkan untuk mengikuti uji kompetensi nasional.Uji kompetensi ditujukan untuk mencapai standar kompetensi lulusan yang memenuhi standar kompetensi kerja ${ }^{1}$.

Penelitian yang dilakukan oleh Abdilah tentang faktor-faktor yang mempengaruhi kelulusan uji kompetensi ners di Stikes Ngudia Husada Madura dengan hasil bahwa ada hubungan antara penyelenggaraan try out dengan kelulusan mahasiswa ners. Faktor indek prestasi kumulatif juga terdapat hubungan dengan kelulusan ners, begitupula gaya belajar mahasiswa juga berhubungan dengan kelulusan ners ${ }^{2}$.

Hasil studi pendahuluan yang dilakukan pada mahasiswa Stikes Jenderal Achmad Yani Yogyakarta pada tanggal 31 Maret 2017 menggunakan data sekunder bahwa tingkat kelulusan mahasiswa ners dalam mengikuti uji kompetensi nasional sesuai SK nomor 902/Puk-Nas/XI/2016 November 2016 masih 68,61\%. Masih ada
$31,39 \%$ mahasiswa ners yang belum lulus uji kompetensi nasional.

Dari latar belakang di atas peneliti tertarik untuk melakukan penelitian tentang faktor-faktor yang mempengaruhi kelulusan mahasiswa ners Stikes Jendral Achmad Yani Yogyakarta dalam mengikuti uji kompetensi nasional. Adapun faktor-faktor yang akan diteliti yaitu faktor prestasi akademik IPK S1 keperawatan, IPK Ners, lingkungan praktik ners, sarana prasarana akademik, kecemasan, tingkat spiritual, kepribadian, jenis kelamin, dan program peminatan.

\section{METODE}

Penelitian ini merupakan penelitian deskriptif korelasi, ruang lingkup penelitiannya Pendidikan Profesi Keperawatan. Penelitian ini dilakukan di Stikes Jenderal Achmad Yani Yogyakarta. Penggunaan pendekatancross-sectional pada penelitian ini karena tidak adanya intervensi apapun dan pengambilan data dilakukan sekali waktu. Populasi dalam penelitian ini adalah mahasiswa ners Stikes Jenderal Achmad Yani Yogyakarta yang mengikuti Uji Kompetensi Nasional Indonesia dengan sampel sebanyak 30 mahasiswa.Teknik sampling yang digunakan menggunakan simple random sampling. 


\section{HASIL}

\section{Tabel 1}

Hasil Uji Korelasi Gamma IPK akademik S1 dengan Ukom $(n=30)$

\begin{tabular}{lccccc}
\hline IPK S1 & \multicolumn{2}{c}{ Ukom } & Total & $\boldsymbol{p}$ & $\mathbf{r}$ \\
\cline { 2 - 4 } & $\begin{array}{c}\text { Komp } \\
\text { eten }\end{array}$ & $\begin{array}{c}\text { Tidak } \\
\text { Kom } \\
\text { peten }\end{array}$ & & & \\
\hline $\begin{array}{l}\text { Dengan } \\
\text { Pujian }\end{array}$ & 5 & 0 & 5 & & \\
\hline $\begin{array}{l}\text { Sangat } \\
\text { Memuask } \\
\text { an }\end{array}$ & 7 & 1 & 8 & 0,002 & 0,836 \\
\hline $\begin{array}{l}\text { Memuask } \\
\text { an }\end{array}$ & 9 & 8 & 17 & & \\
\hline \multicolumn{1}{c}{ Total } & 21 & 9 & 30 & & \\
\hline
\end{tabular}

Tabel 1 menunjukkan hasil analisis tabulasi silang IPK akademik dengan pujian yang lulus uji kompetensi perawat sebanyak 5 responden. Hasil uji korelasi antara IPK akademik dengan kelulusan uji kompetensi didapatkan hasil p-value 0,002 . Hasil tersebut menunjukkan bahwa ada hubungan IPK akademik jenjang S1 keperawatan dengan kelulusan uji kompetensi perawat, karena p-value kurang dari alpha $(0,05)$. Nilai keeratan hubungan penelitian ini dalam rentang kategori sangat kuat yaitu 0,836 .

Tabel 2

\begin{tabular}{|c|c|c|c|c|}
\hline \multicolumn{5}{|c|}{$\begin{array}{c}\text { Hasil Uji Korelasi Gamma IPK Ners } \\
\text { dengan Ukom }(\mathbf{n = 3 0})\end{array}$} \\
\hline \multirow[t]{2}{*}{ IPK NERS } & \multicolumn{2}{|c|}{ Ukom } & \multirow[t]{2}{*}{ Total } & \multirow[t]{2}{*}{$\mathbf{p}$} \\
\hline & Kompeten & $\begin{array}{c}\text { Tidak } \\
\text { Kompeten }\end{array}$ & & \\
\hline $\begin{array}{l}\text { Dengan } \\
\text { Puijian }\end{array}$ & 16 & 4 & 20 & 0,10 \\
\hline
\end{tabular}

\begin{tabular}{lllll}
\hline $\begin{array}{l}\text { Sangat } \\
\text { Memuaskan }\end{array}$ & 5 & 5 & 10 & 6 \\
\cline { 1 - 4 } Total & 21 & 9 & 30 & \\
\hline
\end{tabular}

Tabel 2 hasil tabulasi silang IPK profesi ners dengan kelulusan uji kompetensi didapatkan 4 responden berpredikat dengan pujian tidak lulus uji kompetensi perawat. Hasil statistic menggunakan gamma antara indek prestasi jenjang profesi ners dengan uji kompetensi didapatkan hasil p-value 0,106. Hasil tersebut menunjukkan tidak ada hubungan karenap-value lebih dari alpha $(0,05)$.

\section{Tabel 3}

\section{Hasil Uji Komparasi Gamma Sarana} Prasarana Akademik dengan Ukom

\begin{tabular}{|c|c|c|c|c|c|}
\hline & \multicolumn{2}{|c|}{$(\mathbf{n}=\mathbf{3 0})$} & \multirow{3}{*}{ Total } & \multirow{3}{*}{$\mathbf{p}$} & \multirow{3}{*}{$\mathbf{r}$} \\
\hline \multirow{2}{*}{$\begin{array}{l}\text { Sarana } \\
\text { Prasaran } \\
\text { Akademik }\end{array}$} & & & & & \\
\hline & Kompeten & $\begin{array}{c}\text { Tidak } \\
\text { Kompeten }\end{array}$ & & & \\
\hline Baik & 9 & 0 & 9 & & \\
\hline Cukup & 12 & 9 & 21 & 0,001 & 1,00 \\
\hline Total & 21 & 9 & 30 & & \\
\hline
\end{tabular}

Tabel 3 menunjukkan tabulasi silang 9 responden dengan kategori persepsi sarana prasarana akademik baik berhasil lulus uji kompetensi perawat. Hasil uji komparasi antara faktor sarana prasarana akademik dengan kelulusan uji kompetensi didapatkan hasil p-value 0,001. Hasil tersebut menunjukkan ada hubungan karenap-value kurang dari alpha (0,05). Nilai (r) atau keeratan 
hubungan dari dua variabel ini sangat kuat yaitu 1,00 .

Tabel 4

\begin{tabular}{|c|c|c|c|c|}
\hline \multicolumn{5}{|c|}{$\begin{array}{c}\text { Hasil Uji Komparasi Gamma Faktor } \\
\text { Lingkungan dengan Ukom }(\mathbf{n}=\mathbf{3 0})\end{array}$} \\
\hline \multirow{2}{*}{$\begin{array}{l}\text { Faktor } \\
\text { Lingkungan }\end{array}$} & \multicolumn{2}{|c|}{ Ukom } & \multirow{2}{*}{ Total } & \multirow{2}{*}{$\mathbf{p}$} \\
\hline & Kompeten & $\begin{array}{c}\text { Tidak } \\
\text { Kompeten }\end{array}$ & & \\
\hline Baik & 3 & 1 & 4 & \multirow{3}{*}{0,807} \\
\hline Cukup & 18 & 8 & 26 & \\
\hline Total & 21 & 9 & 30 & \\
\hline
\end{tabular}

Tabel 4 hasil analisis tabulasi silang 1 responden dengan kategori persepsi lingkungan baik, namun tidak lulus uji kompetensi perawat. Hasil uji komparasi antara faktor lingkungan dengan uji kompetensi didapatkan hasil $p$ value 0,807 . Hasil tersebut menunjukkan tidak ada hubungan antara faktor lingkungan dengan kelulusan uji kompetensi perawat karena p-value lebih dari alpha $(0,05)$.

\section{Tabel 5}

Tabulasi Silang Tingkat Spiritual Dengan Kelulusan Uji Kompetensi

\begin{tabular}{lcccc} 
& \multicolumn{3}{c}{$(\mathbf{n = 3 0 )}$} & \\
\hline \multirow{2}{*}{ Spiritual } & \multicolumn{2}{c}{ Ukom } & Total & $\mathbf{p}$ \\
\cline { 2 - 4 } & Kompeten & $\begin{array}{c}\text { Tidak } \\
\text { Kompeten }\end{array}$ & \\
\hline Tinggi & 18 & 7 & 25 & \\
\cline { 1 - 4 } Sedang & 3 & 2 & 5 & 0,617 \\
\cline { 1 - 4 } Total & 21 & 9 & 30 & \\
\hline
\end{tabular}

Tabel 5 menunjukkan tabulasi silang aspek spiritual dengan kelulusan uji kompetensi yang didapatkan sebagaian besar responden tingkat spiritual tinggi dengan kelulusan sebanyak 18 responden.Hasil uji statistik gamma menunjukkan nilai $p$-value sebesar 0,617 yang artinya tidak ada hubungan antara tingkat spiritual mahasiswa prosfesi ners dengan kelulusan uji kompetensi perawat.

\section{Tabel 6}

Tabulasi Silang Tingkat Kepribadian Dengan Kelulusan Uji Kompetensi

\begin{tabular}{lcccc} 
& \multicolumn{2}{c}{$(\mathbf{n = 3 0 )}$} & & \\
\hline \multirow{2}{*}{ Kepribadian } & \multicolumn{2}{c}{ Ukom } & Total & $\mathbf{p}$ \\
\cline { 2 - 4 } & Kompeten & $\begin{array}{c}\text { Tidak } \\
\text { Kompeten }\end{array}$ & & \\
\hline Introvert & 4 & 2 & 6 & \\
\hline Ekstrovert & 17 & 7 & 24 & 0,846 \\
\hline Total & 21 & 9 & 30 & \\
\hline
\end{tabular}

Tabel 6 menunjukkan tabulasi silang aspek kepribadian dengan kelulusan uji kompetensi perawat dengan hasil tipe kepribadian ekstrovert mendominasi sebanyak 17 responden dengan lulus uji kompetensi perawat. Hasil uji statistik gamma menunjukkan nilai $p$-value sebesar 0,846 yang artinya tidak ada hubungan antara tipe kepribadian dengan kelulusan uji kompetensi.

Tabel 7

Tabulasi Silang Tingkat Kecemasan Dengan Kelulusan Uji Kompetensi $(\mathbf{n}=\mathbf{3 0})$

Ukom $\quad$ Total $p$




\begin{tabular}{|c|c|c|c|c|}
\hline Cemas & Kompeten & $\begin{array}{c}\text { Tidak } \\
\text { Kompeten }\end{array}$ & & \\
\hline Tinggi & 13 & 3 & 16 & \multirow{3}{*}{0,143} \\
\hline Sedang & 8 & 6 & 14 & \\
\hline Total & 21 & 9 & 30 & \\
\hline
\end{tabular}

Tabel 7 menunjukkan tabulasi silang tingkat kecemasan dengan kelulusan uji kompetensi menunjukkan hasil sebagian besar responden dalam kategori cemas tinggi dan lulus uji kompetensi. Hasil uji statistik gamma menunjukkan nilai $p$-value 0,143 yang artinya tidak ada hubungan antara tingkat kecemasan mahasiswa dengan kelulusan uji kompetensi perawat.

\section{Tabel 8}

Tabulasi Silang Jenis Kelamin dengan Kelulusan Uji Kompetensi

\begin{tabular}{ccccc}
\hline Jenis & \multicolumn{2}{c}{ Ukom } & Total & p \\
\cline { 2 - 4 } Kelamin & Kompeten & $\begin{array}{c}\text { Tidak } \\
\text { Kompeten }\end{array}$ & & \\
\hline $\begin{array}{c}\text { Perempu } \\
\text { an }\end{array}$ & 10 & 5 & 15 & \\
\hline $\begin{array}{c}\text { Laki- } \\
\text { Laki }\end{array}$ & 11 & 4 & 15 & \\
\hline Total & 21 & 9 & 30 & \\
\hline
\end{tabular}

Tabel 8 menunjukkan hasil tabulasi silang antara jenis kelamin dengan kelulusan uji kompetensi perawat dengan hasil laki-laki lebih banyak lulus daripada perempuan sebanyak 11. Hasil uji statistik didapatkan nilai $p$-value 1,00 yang artinya tidak ada hubungan antara jenis kelamin dengan kelulusan uji kompetensi perawat.

\section{Tabel 9}

\begin{tabular}{|c|c|c|c|c|}
\hline \multirow{3}{*}{ Peminatan } & & & & \\
\hline & \multicolumn{2}{|c|}{ Ukom } & \multirow{2}{*}{ Total } & \multirow{2}{*}{$\mathbf{p}$} \\
\hline & Kompeten & $\begin{array}{c}\text { Tidak } \\
\text { Kompeten }\end{array}$ & & \\
\hline IGD & 9 & 5 & 14 & \multirow{5}{*}{0,976} \\
\hline OK & 8 & 4 & 12 & \\
\hline HD & 2 & 0 & 2 & \\
\hline ICU & 2 & 0 & 2 & \\
\hline Total & 21 & 9 & 30 & \\
\hline
\end{tabular}

Tabel 9 menunjukkan hasil tabulasi silang antara peminatan dengan kelulusan uji kompetensi perawat dengan hasil peminatan IGD lebih banyak lulus dengan jumlah 9. Hasil uji statistik didapatkan nilai $p$-value 0,976 yang artinya tidak ada hubungan antara program peminatan dengan kelulusan uji kompetensi perawat.

\section{PEMBAHASAN}

Hasil analisis tabulasi silang antara IPK S1 keperawatan dengan kelulusan uji kompetensi didapatkan 5 responden dengan predikat dengan pujian berhasillulus uji kompetensi perawat. Hasil uji statistik juga menunjukkan ada hubungan antara indek prestasi akademik S1 keperawatan dengan kelulusan uji kompetensi perawat di Stikes Jenderal Achmad Yani Yogyakarta. Sesuai dengan hasil penelitian Abdilah yang melakukan penelitian hubungkan IPK dengan UKNI pada mahasiswa profesi di Stikes Ngudia Husada Madura dengan hasil ada hubungan yaitu $p$-value $0,002<(0,05)^{2}$. 
Djamarah, (2002) dalam Iskandar (2016)mengatakan IPK merupakan alat ukur untuk melihat prestasi akademik dan sering dipakai dalam penelitian untuk mengukur learning outcome di perguruan tinggi. Prestasi akademik menjadi salah satu indikator keberhasilan proses pendidikan ${ }^{3}$.

Stikes Jenderal Achmad Yani Yogyakarta telah menetapkan kurikulum sesuai dengan ketentuan AIPNI dan mahasiswa juga dibekali materi praktik lapangan yang dimulai semester 2 yaitu praktik keperawatan dasar I dan II, dilanjutkan pada semester 4 yaitu praktik keperawatan dewasa I, pada semester 5 mahasiswa mendapatkan praktik klinik keperawatan dewasa II dan keperawatan jiwa. Mahasiswa mendapatkan praktik keperawatan anak dan gawat darurat di semester 6.Semester 7 mahasiswa mendapatkan materi praktik keperawatan maternitas dan gawat darurat II.Semester 8 mahasiswa mendapatkan materi praktik keperawatan keluarga, gerontik, komunitas, dan terapi komplementer ${ }^{4}$.

Hasil analisis tabulasi silang antara IPK ners dengan kelulusan uji kompetensi didapatkan 4 responden dengan predikat dengan pujian tidak lulus uji kompetensi perawat. Hasil uji statistik menunjukkan hasil $p$-value 0,106 yang artinya tidak ada hubungan.

Sesuai ketentuan Permendikbud tahun 2014, untuk predikat dengan pujian pada program profesi antara rentang 3,76 sampai dengan 4,00. IPK profesi diperoleh setiap mahasiswa dengan mengakumulasikan nilai setiap stase praktik keperawatan selama 1 tahun menjalankan praktik di rumah sakit, Puskesmas, keluarga, dan komunitas ${ }^{5}$.

Hasil analisis uji korelasi antara faktor sarana prasarana akademik dengan uji korelasi gamma didapatkan hasil p-value 0,001. Hasil tersebut dapat diartikan ada hubungan antara sarana prasarana akademik dengan kelulusan uji kompetensi perawat. Dari hasil analisis tabulasi silang 9 responden dengan kategori persepsi saran prasarana akademik baik, dengan hasil lulus uji kompetensi perawat. Keeratan hubungan dua variabel tersebut juga dalam rentang kategori sangat kuat yaitu 1,00. Penelitian ini berbeda dengan yang dilakukan Iskandar, yang menghubungkan sekolah (metode mengajar dosen, jadwal belajar, interaksi dosen dengan mahasiswa, disiplin, sarana dan prasarana belajar-mangajar) dengan prestasi belajar mahasiswa keperawatan dengan hasil tidak ada hubungan ${ }^{3}$. 
Hasil uji korelasi antara faktor lingkungan praktik dengan kelulusan uji kompetensi didapatkan p-value 0,807.Hasil tersebut menyebutkan tidak ada hubungan antara faktor lingkungan dengan kelulusan uji kompetensi perawat.

Tingkat spiritual responden dalam menghadapi uji kompetensi nasional perawat sebagian besar dalam kategori tinggi yaitu 25 responden.Spiritual adalah sebuah konsep yang luas dengan berbagai sudut pandang.Secara umum, dinilai sebagai rasa berkesinambungan terhadap sesuatu yang lebih besar dari diri kita sendiri, dan melibatkan pencarian makna dalam hidup ${ }^{6}$.Tingkat spiritual adalah gambaran kedewasaan atau kapasitas spiritual seseorang ${ }^{7}$.

Namun demikian dari tingkat spiritual yang tinggi sejumlah 25 responden ada 7 yang tidak kompeten dalam uji kompetensi perawat.Berbeda dengan penelitian Permatasari yang menghubungkan tingkat spiritualitas dengan motivasi sembuh pada pasien kritis dengan hasil ada hubungan. Hasil uji statistik penelitian tersebut dengan uji spearman rho yaitu 0,004 lebih kecil dari alpha $(0,05)^{8}$.

Tabulasi silang aspek spiritual dengan kelulusan uji kompetensi didapatkan sebagaian besar responden tingkat spiritual tinggi dengan kelulusan sebanyak 18 responden.Hasil uji statistik menunjukkan tidak ada hubungan antara spiritual dengan kelulusan uji kompetensi perawat. Walaupun tidak ada hubungan dari hasil tabulsasi silang sebagian besar responden yang memiliki tingkat spiritual tinggi sebanyak 18 responden dengan hasil lulus uji kompetensi. Banks (1980) dalam Stanle menyebut spiritual sebagai kekuatan yang menyatukan, memberi makna pada kehidupan dan terdiri dari nilai-nilai individu, persepsi, juga keterikatan diantara individu.Seseorang mungkin menggambarkan pengalaman spiritual sebagai sesuatu yang suci atau transenden dengan perasaan saling keterikatan 9 .

Tipe kepribadian responden sebagian besar dengan tipe ekstrovert sebanyak 24 responden. Tipe kepribadian ekstrovert, bila seseorang dalam keadaan tertekan justru akan menggabungkan diri dengan orang banyak sehingga bebannya berkurang. Individu berkepribadian ekstrovert orientasinya tertuju keluar, terutama dipengaruhi oleh dunia objektif (dunia di luar dirinya) Jung dalam Suryabrata. Berbeda dengan tipe kepribadian introvert, yaitu individu dengan kepribadian yang cenderung untuk menarik diri dan menyendiri, terutama 
dalam keadaan emosional, atau sedang menghadapi masalah dan konflik $^{10}$.

Tabulasi silang aspek kepribadian dengan kelulusan uji kompetensi perawat dengan hasil tipe kepribadian ekstrovert mendominasi sebanyak 17 responden dengan lulus uji kompetensi. Hasil uji statistik menunjukkan tidak ada hubungan antara tipe kepribadian dengan kelulusan uji kompetensi perawat.Carl Gustav Jung (1950) dikutip oleh Sabri bahwa tipe kepribadian ekstrovert arah minatnya pada dunia kenyataan yang dapat dilihat.Ekstrovert bersifat praktis, suka cepat bertindak dan mudah membuat keputusan $^{11}$.

Tingkat kecemasan responden saat menghadapi uji kompetensi nasional perawat sebagian besar dalam kategori tinggi sebanyak 16 responden.Cemas menurut Stuart adalah kekhawatiran yang tidak jelas dan menyebar yang berkaitan dengan perasaan tidak pasti dan tidak berdaya. Tingkat kecemasan yang tinggi dapat terlihat tanda seperti lapangan persepsi individu sangat sempit, individu cenderung berfokus pada sesuatu yang rinci dan spesifik, semua perilaku ditujukan untuk mengurangi kecemasan, dan individu memerlukan banyak pengarahan untuk berfokus pada area lain. Respon fisiologis yang sering muncul pada Deby, Rahayu, Sujono tingkat kecemasan tinggi yaitu napas pendek, nadi dan tekanan darah meningkat, berkeringat, ketegangan dan sakit kepala.Respon kognitif seperti lapang persepsinya sempit dan tidak dapat menyelesaikan masalah.Respon perilaku dan emosi seperti perasan ancaman meningkat $^{12}$.

Tabulasi silang tingkat kecemasan dengan kelulusan uji kompetensi menunjukkan hasil sebagian besar responden dalam kategori cemas tinggi dan lulus uji kompetensi. Dari 16 responden dengan tingkat kecemasan yang tinggi namun hasil yang didapatkan dari uji kompetensi lulus yaitu 13, sedangkan yang 3 belum lulus. Bahkan tidak ada responden yang menunjukkan dengan tingkat kecemasan rendah.Dari hasil ini menunjukkan belum tentu individu yang dalam keadaan kecemasannya tinggi kemudian tidak dapat mencapai tingkat kelulusan dalam uji kompetensi perawat.Pada dasarnya, kecemasan merupakan hal wajar yang pernah dialami oleh setiap manusia.Kecemasan sudah dianggap sebagai bagian dari kehidupan sehari-hari.Kecemasan adalah suatu perasaan yang sifatnya umum, di mana seseorang merasa ketakutan atau kehilangan kepercayaan diri yang tidak jelas asal maupun wujudnya ${ }^{13}$.Hasil uji 
statistik menunjukkan tidak ada hubungan tingkat kecemasan dengan kelulusan uji kompetensi perawat di Stikes Jenderal Achmad Yani Yogyakarta. Hasil tersebut sejalan dengan penelitian yang dilakukan Amir, Iryani, dan Isrona (2016) yang meneliti hubungan tingkat kecemasan dengan kelulusan OSCE di Universitas Andalas yang diuji dengan Gamma Somer's dengan hasil tidak ada hubungan yaitu nilai $p(0,461)$ lebih besar dari alpha $(0,05)^{14}$.

Hasil tabulasi silang antara jenis kelamin dengan kelulusan uji kompetensi perawat dengan hasil laki-laki lebih banyak lulus daripada perempuan sebanyak 11. Hasil uji statistik dengan uji chi square didapatkan nilai p-value 1.00 yang artinya tidak ada hubungan antara jenis kelamin dengan kelulusan uji kompetensi perawat. Hasil tersebut sejalan dengan penelitian yang dilakukan oleh Yanti dan Warsito yang meneliti hubungan antara jenis kelamin dengan kualitas dokumentasi yang memperoleh hasil $p$ value $=0,659$ yang artinya tidak ada hubungan ${ }^{14}$. Menurut Ilyas jenis kelamin akan memberikan dorongan yang berbeda, jenis kelamin laki-laki memiliki dorongan lebih besar daripada wanita karena tanggung jawab laki-laki lebih besar ${ }^{15}$.
MenurutHungu, jenis kelamin (seks) adalah perbedaan antara perempuan dengan laki-laki secara biologis sejak seseorang lahir. Seks berkaitan dengan tubuh laki-laki dan perempuan, yang manapada laki-laki memproduksi sperma, sementara perempuan menghasilkan sel telur dan secara biologis mampu untuk menstruasi, hamil, dan menyusui. Perbedaan biologis dan fungsi biologis laki-laki dan perempuan tidak dapat dipertukarkan di antara keduanya, dan fungsinya tetap dengan laki-laki dan perempuan pada segala ras yang ada di muka bumi. Menurut kamus besar bahasa Indonesia jenis kelamin adalah sifat jasmani atau rohani yang membedakan dua makhluk sebagai betina dan jantan atau wanita dan pria $^{16}$.

Hasil tabulasi silang antara peminatan dengan kelulusan uji kompetensi perawat dengan hasil peminatan IGD lebih banyak lulus dengan jumlah 9. Hasil uji statistik didapatkan nilai $p$-value 0.976 yang artinya tidak ada hubungan antara program peminatan dengan kelulusan uji kompetensi perawat.Program pemintan di Stikes Jenderal Achmad Yani Yogyakarta merupakan program tambahan sebanyak 4 SKS bagi mahasiswa yang sudah menyelesaikan semua stase dalam profesi 
ners.Dengan program peminatan diharapkan mahasiswa ners lebih terampil dan terarah pada salah satu aspek peminatan dalam pemberian asuhan keperawatan kepada pasien.Namun demikian, jika merujuk pada kurikulum AIPNI (Asosiasi Institusi Profesi Ners Indonesia) untuk program peminatan tidak diwajibkan. Dari hasil penelitian ini juga tidak ada hubungan antara program peminatan dengan kelulusan uji kompetensi ners di Stikes Jenderal Achmad Yani Yogyakarta.

Peminatan mahasiswa ners Stikes Jenderal Achmad Yani Yogyakarta sebagian besar memilih IGD yaitu 14 responden. Peminatan adalah salah satu sks dalam program studi profesi ners di Stikes Jenderal Achmad Yani Yogyakarta. Mahasiswa profesi ners wajib mengikuti peminatan yang mempunyai 4 sks dengan berbagai pilihan seperti IGD, ICU, Bedah, dan Hemodialisa (HD).Pelaksanaan peminatan selama 4 minggu, dengan tugas yang spesisfik sesuai jalur peminatan yang diambil ${ }^{4}$.

\section{KESIMPULAN}

Faktor-faktor yang berhubungan dengan kelulusan uji kompetensi mahasiswa profesi ners di stikes Jenderal Achmad Yani Yogyakarta yaitu IPK S1 keperawatan dan faktor sarana prasaran akademik.Sedangkan faktor-faktor yang tidak behubungan dengan kelulusan uji kompetensi keperawatan yaitu IPK ners, lingkungan praktik ners, tingkat spiritual, tipe kepribadian, kecemasan, jenis kelamin dan program peminatan.

\section{DAFTAR PUSTAKA}

1. UU Keperawatan tahun 2014. Praktik Keperawatan. Nomor 38. Jakarta

2. Abdillah, A. 2016. Faktor-faktor yang mempengaruhi kelulusan uji kompetensi ners Indonesia. JPAP. Vol 2 No 2. 373-380

3. Iskandar, 2016. Faktor-faktor yang memengaruhi keberhasilan belajar mahasiswa pada model pembelajaran student centered learning di Stikes Jenderal Achmad Yani Yogyakarta.

4. Kurikulum PSIK, (2010-2014). Kurikulum Program Studi Ilmu Keperawatan Stikes Jenderal Achmad Yani Yogyakarta. Yogyakarta

5. Permendikbud tahun 2014. Standar nasional pendidikan tinggi. No 49 . Jakarta

6. Krentzman, A. R. Spirituality Definition. 2016. Diakses via http://www.takingcharge.csh.umn.edu/ enhanceyourwellbeing/purpose/spiritua lity 
7. Spiritual Science Research Foundation. The Scale of Spiritual Level. 2013. Diakses via http://www.spiritualresearchfoundation .org/spiritual-practice/spiritualgrowth/spiritual-level

8. Permatasari, D. Hubungan tingkat spiritualitas dengan motivasi sembuh pasien kritis di RSUD Dr. Moewardi Surakarta. Skripsi. 2016. Departemen Keperawatan Fakultas Kedokteran, UNDIP, Semarang, 2017.

9. Stanley, M., \& Beare, P. G.. Buku Ajar Keperawatan Gerontik. Jakarta: EGC. 2006

10. Suryabrata, S. Psikologi kepribadian, Raja grafindo persada: Jakarta. 2015

11. Sabri, M. Hubungan Antara Tipe Kepribadian Introvert dengan Ekstrovert pada Mahasiswa UII Jogjakarta. 2001. Skripsi. Tidak dipublikasikan

12. Stuart, Gail W. Buku Saku Keperawatan Jiwa (Edisi 5). Jakarta: Penerbit Buku Kedokteran EGC. 2007 13. Sutardjo W.. Pengantar Psikologi Abnormal. Bandung: Refika Aditama. 2005.

14. Amir, Iryani, dan Isrona, Hubungan Tingkat Kecemasan dalam Menghadapi Objective Structured Clinical Examination (OSCE) dengan
Kelulusan OSCE pada Mahasiswa Fakultas Kedokteran Universitas Andalas. Jurnal Kesehatan Andalas. Vol 5 No 1. 2016.

15. Yanti dan Warsito, 2013. Hubungan karakteristik perawat, motivasi, dan supervisi dengan kualitas dokumentasi proses asuhan keperawatan. Jurnal Manajemen Keperawatan. Volume 1 Nomor 2 2013.107-114

16. Ilyas. 2001. Teori, Penilaian dan Penelitian Kinerja. Cetakan Kedua. Jakarta: Pusat Kajian Ekonomi Kesehatan FKM-UI. 